\title{
Aristoteles Felsefesinde Birey ve Devlet Açısından Eğitim Meselesi
}

\author{
Doç. Dr. Sebile Başok Diş \\ Necmettin Erbakan Üniversitesi, Sosyal ve Beşeri Bilimler Fakültesi \\ Felsefe Bölümü \\ sebile_basok2000@yahoo.com
}

Öz

Aristoteles, eğitim konusunu insana özgü olduğunu düşündüğü niteliklerden yola çıkarak hem birey hem de devlet açısından ele alır. Ona göre "toplumsal bir hayvan" olan insan ancak toplum ve devlet içinde iyi bir yaşama kavuşabilir. Diğer yandan bireyin amacı da iyi yaşama ulaşmaktır. Bu bakımdan insanın iyi bir topluma ve iyi bir devlete ihtiyacı vardır. Kişilerin eğitimi onların iyi bir yaşama ulaşmaları için gereklidir ve bu eğitimi sağlaması gereken de devlettir. Halkın eğitimini devletin sorumluluğu altında gören Aristoteles, bir insanın nasıl yetiştirilmesi gerektiği sorusunu farklı açlardan ele alarak yanıtlar. Bu çalışmada Aristoteles'in eğitim konusunu, birey ve devlet açısından nasıl ele aldığı gösterilmeye çalışılacaktır.

Anahtar Kelimeler: Aristoteles, eğitim, insan, devlet, erdem.

\section{The Issue of Education within the Context of Individual and State in Aristotle's Philosophy}

\begin{abstract}
Aristotle deals with the concept of education from the viewpoint of both individual and state by looking at the qualities that he considers human-specific. According to him, human being who is by nature a "social animal" can attain a better life only in society and state. On the other hand, the aim of the individual is to achieve the better life. In this regard, human beings need a good society and a good state. Training of persons is a key to achieve their good life and the state should supply this training. Aristotle, who argues that the state is responsible for the public education, answers the question of how a person should be trained by considering different perspectives. This study attempts to indicate how Aristotle deals with the concept of education within the context of individual and state.
\end{abstract}

Keywords: Aristotle, education, human, state, virtue. 


\section{GİRIŞ}

Aristoteles'in eğitim konusunu Politika adlı eserinde ele almış olması, onun eğitime bakışına işaret etmesi bakımından oldukça anlamlıdır. $\mathrm{O}$, bu eserinde kent devletinin doğasını ve farklı yönetim şekillerini ele alırken, iyi devlete ve iyi yurttaşa ilişkin görüşlerini de ortaya koyar. Eğitim meselesi ona göre hem en iyi yurttaş hem de en iyi devlet biçimi ile doğrudan ilişkilidir. Eğitim, iyi bir insan ve iyi bir yurttaş olmak için gereklidir ve bu nedenle iyi bir devlet, yurttaşlarının eğitimine ilgisiz kalamaz. Sparta'yı eğitime verdiği önem nedeniyle öven ve yalnızca Spartalıların ve birkaç devletin yasa yapıcılarının eğitim konusuyla ilgilendiğini belirten Aristoteles, bir devletin en önemli meselelerinden birinin eğitim olduğu ve bu nedenle eğitimin nasıl yapılacağının yasalar tarafından belirlenmesi gerektiği iddiasındadır (Aristoteles, 2017, s. 232).

Aristoteles eğitim ile ilgili görüşlerinin önemli bir kısmını Politika adlı eserinde ortaya koyar. Esere göre iyi bir yurttaşın yetiştirilmesi için devletin vereceği eğitim gereklidir ancak bu eğitim kendi başına yeterli değildir. Aristoteles, iyi bir yurttaşın yetiştirilmesi meselesini o kişi daha dünyaya gelmeden önceki koşullarla ilişkilendirir ve bu hususta anne baba adayına da sorumluluk yükler. İnsanların nasıl yetiştirileceği meselesini onları dünyaya getirecek anne-baba adayının hangi yaşta çocuk sahibi olacağı gibi konularla ilişkilendirerek oldukça geniş bir çerçeve içinde ele alır. Doğan çocukların nasıl beslenmesi gerektiği, ağlamalarına izin verilip verilmeyeceği, küçük çocukların kimlerle zaman geçireceği gibi konular doğrudan okul hayatıyla ilgisi olmasalar da Aristoteles bunları eğitim konusuna dahil eder. Okul öncesi eğitim konusundaki görüşlerini eğitim bağlamında ayrıntılı bir şekilde dile getiren Aristoteles, okullarda ne tür bir eğitim verilmesi gerektiğini, okul müfredatında hangi konulara yer verileceğini ve bunların niçin, ne şekilde müfredata konması gerektiğini etraflıca anlatır. Okullarda beden eğitimi, müzik, okuma-yazma gibi konulara yer verilmesi gerektiğini söyleyen Aristoteles, bunların niçin eğitim açısından gerekli olduğunu açıklar ve bu konuların eğitiminde aşırılıklardan uzak kalınması gerektiğini ileri sürer. Ahlaki kaygıları ön planda olan Aristoteles, eğitim meselesini de ahlak ve erdem kavramlarını merkeze alarak ele alır. Bu çerçevede ona göre ister müzik eğitimi olsun isterse beden eğitimi, verilecek her tür eğitim öğrencinin ahlakı üzerinde ne tür bir etki bırakacağına göre değerlendirilmelidir.

Bu çalışmada eğitim felsefesi alanında önemli etkisi olmuş filozoflardan biri olan Aristoteles'in eğitim anlayışının ortaya konması amaçlanmıştır. Onun eğitim anlayışının ele alındığı bu çalışmada konuyla bağlantılı olduğu için onun insan, kadın erkek, çocuk, köle, efendi, devlet, erdem ve mutluluk gibi konularla ilgili görüşleri de ele alınmış ve tartışılmıştır. İlk bölümde Aristoteles için eğitimin niçin önemli olduğu ortaya konmaya çalışılırken genel olarak eğitimin insan gelişimi açısından oynadığı role de dikkat çekilmiştir. Çalışmanın sonraki bölümünde iyi bir yaşam için eğitimin şart olduğunu düşünen Aristoteles'in iyi yaşamdan ne anladığı, bu yaşamı mutlulukla ve erdemle nasıl ilişkilendirdiği açıklanmaya çalışılmıştır. Üçüncü bölümde eğitim işini bireylerin kişisel tercihlerine bırakmayacak kadar önemli bulan Aristoteles'e göre devletin ne tür bir eğitim vermesi gerektiği açıklanmıştır. 


\section{EĞİTIMIN AMACI VE ÖNEMI}

Aristoteles felsefesinde etik ve politika, insan felsefesinin kurucu alanlarını oluşturdukları için birbirleriyle yakından ilişkilidirler ve bu nedenle birbirinden ayrı şekilde soruşturulamazlar (Erkızan, 2016, s. 40). Aristoteles bu nedenle karakter inceleme bilimi anlamında etiğin politikadan başka bir şeyin dalı olamayacağını, karakter ile ilgili uğraşın politikanın dalı ve başlangıç noktası olduğunu söyler (Aristoteles, 2016, s. 23). Aristoteles için etik ile politika arasındaki ilişki derin ve vazgeçilmez olmakla beraber Aristoteles'in bunları birbirine indirgemediği de hatırda tutulmalıdır (Erkızan, 2012a, s. 124). Aristoteles için etik ve politika birbiriyle bağlantılıdır ve etik anlayışının merkezinde yer alan iyi yaşam, onun siyaset anlayışının odağında bulunan iyi toplumda yaşama ile mümkün hale gelir. Aristoteles'in erdem etiği de kişinin kendisini gerçekleştirmesinin toplum hayatı içinde bazı erdemleri karakter özelliği haline getirmesiyle mümkün olduğunu varsaydığı için bu etik iyi toplumu, iyi insanın varlık koşulu sayar (Küçükalp, 2019, s. 122).

Aristoteles, etik ve politika alanında yaptığ 1 soruşturmalar neticesinde siyasetin amacının insanları iyi kılmak olduğu, insanların iyi ve mutlu olabilmesi için siyasetin gerekli olduğu ancak siyasal mutluluğun da ahlaktan geçtiği sonucuna varmıştır (Akdemir, 2010, s. 82). Aristoteles'e göre doğası gereği toplumsal bir varlık olan insanın yetkinlik kazanması yalnızca devlet içinde mümkündür. Bu nedenle devlet bir gerekliliktir. Toplumsallık Aristoteles için insanın asli yönlerinden biridir. Bu nedenle herhangi bir nedenle toplumsal yönünü açığa çıkaramamış, toplumsallık kazanamamış bir kimse gerçek anlamda bir insan olmayacaktır. Devlet, insan doğasının toplumsallı̆̆ nedeniyle, bu doğanın tabii bir sonucu olarak ortaya çıkmış doğal bir kurumdur ve temel işlevi de yine insan doğası ile ilgilidir: İnsan doğasındaki potansiyellerin aktif hale gelmesini sağlamak.

Aristoteles, bir şehrin iyi ve erdemli olmasını, o anayasayı paylaşan insanların iyi ve erdemli olmasına bağlar. Bu nedenle insanların iyi ve erdemli olması iyi bir devletin var olabilmesi ile ilişkilidir. İnsanların nasıl iyi ve erdemli olacağı meselesi bu açıdan çok önemlidir. İnsanda doğasının, alışkanlıklarının ve aklının uyum içinde olması, onun iyi ve erdemli bir insan olması için gereklidir. Ancak bunlar her zaman birbiriyle uyuşmamaktadır. Eğitimin rolü tam bu noktada başlar (Arslan, 2018, s. 320-321).

Bu noktada yalnızca Aristoteles için eğitimin öneminden değil, genel olarak eğitimin öneminden bahsetmek yerinde bir davranış olacaktır. Kabul edileceği üzere eğitim bilgi edinmenin en temel yoludur. Bu nedenle eğitim hakkı her vatandaş için aslidir. Eğitim olmadığı takdirde insan, büyük ölçüde anlayamadığı dünyada kaybolup gidecektir. Tam olarak kendini gerçekleştiremediği gibi deneyimlerini de anlamlandıramayacaktır. Vatandaşlarına eğitim hakkı tanımayan bir devlet, onların kendilerini gerçekleştirmelerine de olanak sağlamıyor demektir (Laski, 2019, s. 39). Ancak devletin, vatandaşlarının eğitim hakkını tanıması her vatandaşa aynı eğitimi vereceği anlamına gelmemektedir. Geçmişte de günümüz dünyasında da eğitim verilirken göz önünde bulundurulan temel unsurlar, toplumsal ihtiyaçlar ile beraber eğitim alacak kişilerin kabiliyet ve potansiyelleri olmuştur. Verilen eğitimin amacına ulaşması, eğitim alan kişinin kapasitesiyle ve istidatlarıyla doğrudan ilişkilidir.

Aristoteles, yüzyıllar önce okul eğitiminin kişinin potansiyellerinin orta çıkması noktasındaki rolünü vurgularken eğitimin önemini de ortaya koymuştur. Eğitimin insan potansiyellerini açığa çıkarmadaki rolü günümüzde yaygın bir şekilde kabul görmektedir. Örneğin, yirminci yüzyılın ünlü düşünürlerinden olan ve Analitik Psikolojinin kurucusu SEFAD, 2021; (45): 337-354 
olarak kabul edilen Carl Gustav Jung, okulun, kişinin kendini gerçekleştirmesinde oynadığı rolü şu şekilde açıklar:

Eğer okullar hiç olmasaydı ve çocuklar tamamen kendi kendilerine kalsalardı ne olurdu sorusunu sorarsak, cevabımız; büyük oranda bilinçdışı kalacakları yönünde olurdu. Bu nasil bir durum olurdu? Bu ilkel bir durum olurdu ve bu gibi çocuklar reşit olduklarmda, doğal zekalarnna rağmen hâlâ ilkel, barbar olarak kalırlardl; aslinda zeki zenciler ya da Buşmanlar kabilesi gibi. İlla aptal olmazlardı ama yalnızca içgüdüsel olarak zeki olurlardı. Cahil ve bu yüzden de kendilerinin ve dünyanin bilincinde olmazlard. Yaşama oldukça düşük bir kültürel seviyeden başlayarak, kendilerini ilkel ırklardan sadece birazcık ayirirlardi. (Jung, 2019, s. 64-65)

Anlaşıldığı üzere eğitim, insanın bilinçdışı bir varlık olarak kalmayıp gerçek anlamda insan olabilmesi için gereklidir. Eğitim olmaksızın insanın aklını ve zekâsını hayatta kalma güdüsünün dışında kullanarak beşeri kurumlar geliştirmesi veya bu kurumlara hizmet etmesi mümkün değildir. Birey eğitim ile hem kendisini hem de içinde yaşadığı dünyayı anlar ve anlamlandırır. Ancak eğitim bireyin kendi başına gerçekleştirebileceği bir faaliyet olmadığı için bu noktada topluma ihtiyacı vardır. Eğitimin toplum tarafından rastgele, düzensiz, gelişigüzel, sistemsiz ve dağınık bir şekilde verilmemesi için de yurttaşlarının iyiliğini düşünen bir devlet gereklidir. Devletin düzenlemesi altında eğitim, sistemsizlikten kurtulacak ve bir program dahilinde yürütülerek belli bir bütünlüğe kavuşacaktır. Ancak eğitimin kişinin potansiyellerini ortaya çıkarıp onu gerçek anlamda insan kılabilmesi, devletin onu hangi amaçla verdiğine bağlıdır. Her eğitim, insanların ahlaken ve zihnen olgunlaşmasını, onları yetkinleştirmeyi hedeflememektedir. Aristoteles de bu durumun farkındadır ve bu nedenle devletin görevinin iyi yaşama kavuşacak iyi insanlar yetiştirmek olduğunu özellikle vurgular. Frederick Copleston'ın da belirttiği gibi "Devlet iyi olmadıkça ve eğitim dizgesi ussal, ahlaksal ve sağhlklı olmadıkça, yurttaşlar iyi olmayacaklardır." (Copleston, 2013, s. 97)

Aristoteles, insanın yaşamını belli bir hedefe göre düzenlememesini büyük bir düşüncesizlik emaresi sayar ve yaşamını kendi tercihine göre yönlendirebilen herkesin güzel yaşamak için kendisine bir hedef koyduğunu ileri sürer. Eğitim de ün, mevki ve zenginlik gibi güzel yaşamak için konulan hedeflerden birisidir (Aristoteles, 1999, s. 13). Ancak görüldüğü gibi eğitim, diğer hedefler gibi yalnızca yaşamını kendi tercihine göre yönlendirebilen kimseler, yani özgür kişiler için bir hedef olabilmektedir. Bu nedenle Bertrand Russell'ın da belirttiği üzere Aristoteles'e göre eğitim, yalnızca yurttaş olacak çocuklar içindir, köle çocukları için değildir. Kölelere yemek pişirmek gibi yararlı sanatlar öğretilebilecektir fakat bu tarz becerilerin kazandırılması eğitimin bir parçası olmayacaktır (Russell, 2002, s. 335). Burada akıllara Aristoteles için bir ayrıcalık olarak görülen eğitimden kadınların ve kölelerin niçin mahrum bırakıldığı sorusu gelmektedir. Bu sorunun yanıtını Aristoteles'in doğa anlayışında bulmak mümkündür.

Aristoteles, öncelikle şeylerin doğal yapılarına uygun olmayan bir alışkanlığ kazanamayacaklarını belirtir (Aristoteles, 2017, s. 41). Ona göre insanlar arasında doğalarının yetkinlikleri bakımından farklılıklar vardır. Özgür erkekler, kadınlar ve köleler sahip oldukları potansiyeller bakımından birbiriyle aynı seviyede değildirler. Embriyo yeterince güçlü olduğunda erkek, yeterince güçlü olmadığında ise kadın meydana gelir (Ross, 2011, s. 197). Bunun bir neticesi olarak kadının sahip olduğu akıl duygular tarafından etkilenmeye yatkın hale gelmektedir. Aristoteles bu akılsallığı akuran, yani yetkin olamama 
olarak nitelendirir. Ona göre bu akıl, doğru düşünceler üretemez (Erkızan, 2013, s. 116). Diğer yandan özgür erkekler ile köleler arasındaki fark, özgür erkeklerle kadınlar arasındaki farktan daha büyüktür. Aristoteles'in ifadesine göre bu fark, insan ile hayvan arasındaki farkı andıracak kadar büyüktür. Aristoteles, evcil hayvanlara benzettiği doğal köleleri, bedenlerini kullanarak çeşitli işler yapmaları dışında kendilerinden bir şey beklenmeyen insanlar olarak tanımlar. Bu insanlar, diğerlerine bağlı, aklı kullanma yetisi az gelişmiş ve bu aklın iradesine sahip olmayan, bedensel ihtiyaçları karşılamaya yarayan kimselerdir (Aristoteles, 2013, s. 31). Aristoteles'e göre kendi kendini belirleyemeyen ve kendinde tam olamayan insan doğal köledir. İnsanın kendi kendini belirleyebilmesi ise onun akıllı bir varlık olmasıyla mümkündür (Erkızan, 2012a, s. 125).

Aristoteles, doğal köleyi uslamlama yeteneğinden yoksun bulur. Doğal kölenin karşısında ise efendi yer alır. Efendi, köleden farklı olarak kendi varlığını akıl ile tanımlayabilmektedir (Erkızan, 2013, s. 114-115). Aristoteles, insanların doğaları itibariyle özgür ya da köle olduğunu söyler ve doğası itibariyle köle olanların kölelik yapmasını uygun bulur. $\mathrm{O}$, ayrıca doğal kölelik ile yasal kölelik (örneğin savaşta ele geçirilen insanların köle olarak kullanılması) arasında bir ayrıma gider ve ikinci tür köleliği doğal kölelik gibi savunmaksızın yasal köleliğin meşruiyeti ile ilgili tartışmalara değinmekle yetinir (Aristoteles, 2013, s. 32-33).

İnsanların akıl yetilerine bakarak onlar arasında efendi, köle, kadın ve çocuk olmak bakımından ayrıma giden Aristoteles, bunlara farklı haklar tanır. Yurttaşlar tam olarak haklara sahipken, kadınların hakları daha düşük seviyededir. Çocukların ve kölelerin hakları ise kadınlardan da daha aşağı düzeydedir (Ross, 2011, s. 334). Aristoteles, insanlar ve onlara verdiği haklar arasındaki ayrımı onların sahip olduğu düşünme yetisinin yetkinliği ile temellendirir. Biraz önce söylediğimiz gibi kölenin düşünüp taşınma yetisi yoktur. Kadında böyle bir yeti vardır fakat ondaki yetinin gücü yoktur. Çocukta var olan bu yeti ise henüz olgunlaşmamıştır (Aristoteles, 2013, s. 378).

Aristoteles bir insanın iyi ve erdemli olması için şu nedenleri etkili görür: doğa, akıl, alışkanlık ve eğitim. Doğa açısından gerekli koşul, erkek olarak doğmaktır. Kişide erkek bedeni ve erkek aklı olmalıdır. Doğanın iyi ve erdemli olmak için tek başına yeterli olmayabileceğini düşünen Aristoteles, onun alışkanlık ve eğitim ile tamamlanması gerekebileceğini söyler (Aristoteles, 2013, s. 243). Bu açıdan bakıldığında Aristoteles'e göre iyi ve erdemli kimselerin, taşıdıkları doğa nedeniyle yalnızca özgür erkekler olabileceği, bu nedenle de yalnızca onların eğitime layık olduğu, köle ve kadınların eğitim hayatının dışında bırakılması gerektiği söylenebilir. Günümüzün akademik dünyasında ise insanlar arasında kapasite ve yetenekler bakımından doğuştan bazı farkların olabileceği kabul edilmekle beraber bu farkların cinsiyet kaynaklı olduğu düşünülmemektedir. Ayrıca kapasite ve yetenek bakımından sınırlı olan bireylerin, başkalarının ihtiyaçlarını karşılayan ve yalnızca bedensel işlerde kullanılan bir araçtan ibaret olduğu görüşü hiçbir şekilde savunulmamaktadır. 


\section{2. İYİ YAŞAMIN ANLAMI VE ERDEMLERLE İLİŞKİSİ}

Aristoteles'e göre insan yaşamının bir amacı vardır ve bu amaç kişinin akla uygun, erdemli bir hayat sürmek için sahip olduğu yetenekleri ortaya çıarmaktır. Kişinin bunu gerçekleştirebildiği yaşam iyi bir yaşamdır. İyi yaşamla kişi, hem aklını yetkinleştirecek hem de bazı karakter erdemleri kazanacaktır. İnsanın sahip olduğu tüm kapasiteleri kullanabildiği böyle bir yaşam, hem akli bakımdan etkin olmayı hem de akli yönlendirmeyi içerir (Erkızan, 2012b, s. 20).

Kişinin iyi yaşama kavuşması bakımından erdemden ve dolayısıyla etikten bahseden Aristoteles, bu konuda modern dönemden oldukça farklı bir yaklaşım sergilemektedir. Bize göre etiğin konusu, başkalarının çıkarını gözeterek eylemde bulunmaktır. Oysa Aristoteles için etik, kişinin genel olarak insanların durumuna, insanların kendine, yakınlarına ve kişinin kendi benliğine duyduğu ilginin sonucu olarak daha büyük bir üçlünün parçasıdır (Rescher, 2019, s. 82). Bu durumu Aristoteles'in arete kavramını nasıl kullandığına bakarak görebiliriz. Aristoteles etiğinin merkezinde bulunan arete kavramı, iyilik ya da mükemmellik gibi bir anlama gelir. Bu bakımdan bir baltanın veya bir argümanın olduğu gibi insanın arete'sinden de bahsedilebilir ki insanın arete'si onun mükemmelliğidir (Barnes, 2002, s. 116). Aristoteles insanın mükemmelliğini onun yaptığı işte, yerine getirdiği işlevde arar. Bu iş, hayvanların da yaptığ 1 bir şey olduğu için sadece yaşamak, beslenmek ya da büyümek değildir. Bu iş, insana özgüdür ve "akıl sahibi olanın -bunun da akla boyun eğen olarak, bir de akla sahip olan ve düşünen olarak- bir tür eylem" yaşamıdır (Aristoteles, 2009, s. 18). Aristoteles'e göre insanın özsel doğasını ve gerçek benliğini akıl oluşturduğu için insanın gerçek ereği de akılsal bir yaşamın yaratılması olmalıdır (Erkızan, 2013, s. 89).

Aristoteles ayrıca iyi yaşamı akıl ve erdemle ilişkilendirerek iyi yaşamı yalnızca haz ve maddiyat ile tanımlayan modern dünyadan ayrilır. Ancak bu, Aristoteles'in hazzı veya maddiyatı reddettiği anlamına gelmemekte, yalnızca onun için bunların öncelikli olmadığı anlamina gelmektedir. Konu iyi yaşam olduğunda bir şekilde mutluluktan da bahsetmek gerekir. Mutluluğu içermeyen bir yaşamın iyi bir yaşam olduğu hiçbir zaman düşünülmemiş, genellikle iyi yaşam ile mutluluk bir şekilde ilişkilendirilmiştir. Modern dünyada iyi yaşam ve mutluluk haz ve maddiyata indirgenmişken, Aristoteles için iyi yaşam erdemlere uygun yaşamdır (Aristoteles, 2016, s. 41-43). Dilimize mutluluk olarak çevrilen eudaimonia, "tüm gücümüzün ve iyiliğimizin kullanılmasından doğan etkinliktir." (Aristoteles, 2013, s. 242) Bu itibarla insanın iyi bir yaşam sürebilmesi ve mutlu olabilmesi için belli dış koşulları sağlaması gerekir ki sonuçta bu bir talih meselesidir. Mutlu insanlar iyi yaşarlar ve iyi durumdadırlar. Kuşkusuz iyi yaşayabilmek ve iyi durumda olabilmek için, yani mutlu olabilmek için kişinin dışsal koşullarının da iyi olması gerekir. Çünkü dışsal iyiler olmadan iyi yaşamak ya da iyi eylemlerde bulunmak hayli güçtür. Bu açıdan dostlar, zenginlik, siyasi güç insana araç gereçler kadar faydalıdır. Diğer taraftan soylu olmamak, çocuk sahibi olmamak ya da güzel olmamak ise insanın iyi yaşama ulaşmasında birer engeldir. Aristoteles, asil olmayan ya da güzel olmayan bir çocuğun mutlu olma şansını fazla bulmaz (Aristoteles, 2017, s. 32-33). Aristoteles'e göre en iyi şey mutluluktur ve bunun için tüm iyiliklerin mümkün olduğu kadar yapılabilmesi gerekir. Bunları yapıp yapamamalarına göre insanlar, yaşamlarında mutluluktan bazen çok, bazen az pay alırlar, bazen de hiç pay alamazlar (Aristoteles, 2013, s. 233). Görüldügü üzere mutluluk için yalnızca içsel koşullar yeterli değildir, dışsal koşullar da gereklidir. Mutluluğun gereklerinden olan dışsal koşulların gerçekleşmesi çoğu zaman kişinin kendi elinde değildir 
ve bu nedenle mutluluk, iradi bir mesele olduğu kadar aynı zamanda bir talih meselesidir. Aristoteles bu gerçeği kabul eder ve dış koşulların, iyi talihin sonucu olduğunu belirterek mutluluk ile talihli olmayı birbiriyle ilişkilendirir (Aristoteles, 2016, s. 189). Aristoteles, dişsal koşulların insan mutluluğu üzerindeki etkisini kabul etmekle beraber bu etkinin sınırlarını vurgulamaktan da geri durmaz. Ona göre dış iyiler olmaksızın mutlu olunamasa da mutlu bir insan olmak için pek çok büyük şeylere gerek olduğu sanılmamalıdır (Aristoteles, 2009, s. 210).

Aristoteles her ne kadar iyi yaşam için zenginliğin bir şart olduğunu söylese de onun için maddi servet sadece bir araçtır. Bu araç doğaya uygun kullanılabileceği gibi doğaya aykırı şekilde de kullanılabilir. Sırf para kazanmak ve gelir arttırmak için kullanılan zenginlik, doğaya aykırıdır. Zenginliğin bu şekilde doğaya aykırı kullanımı insanı mutlu kılmadığı veya mutluluğu arttırmadığı için iyi yaşamın temeli değildir (Kanat, 2013, s. 212213). Ayrıca insani değerlerin rehber alınması gerekirken, zenginliğin amaçlanması politik düzeni bozacaktır (Nussbaum' 2018, s. 144). Aristoteles'in maddiyata bakışını onun kendi sözleriyle özetlemek mümkündür: "İyi bir toplumda insanlar ne işçi ne de iş adamı gibi yaşamalıdır. Çünkü her ikisi de insanın kendisini bir bütün olarak gerçekleştirmesine izin vermez."(Akt. Erkızan, 2013, s. 41) Çalışmanın gerekliliğini inkâr etmeyen Aristoteles, çalışmanın amacının, insanın özgürce yaşayabileceği zamanı elde etmesi olduğunu söyler (Aristoteles, 2013, s. 257).

Bir görev ve zorunluluk tarafından işgal edilmeyen zaman anlamına gelen schole kavramı Aristoteles için oldukça önemlidir. Ona göre schole, eudaimonia'nın koşullarından biridir. Bu nedenle insanlar özgürce yaşayacakları zamana sahip olmak için çalışmalıdırlar (Erkızan, 2013, s. 41). Schole, kendi telos'unu kendi içinde taşıyan eylemlerin gerçekleştirilebileceği özgür zamandır. İnsan schole ile ihtiyaçların dayatmasından kurtularak ereği kendisinde olan eylemlere yönelebilir ki bu eylemler düşünsel eylemlerdir. Düşünsel yaşam ancak schole üzerinde yükselebilmektedir (Erkızan, 2012a, s. 90). Aristoteles, tam mutluluğun bir teori etkinliği olduğu iddiasındadır. Ona göre en mutlu olanlar tanrılardır ve onların etkinliği olsa olsa bir teori etkinliğidir. İnsanlar da bu tür etkinliğe benzer etkinlikte bulundukları ölçüde mutlu olurlar (Aristoteles, 2009, s. 209). Bu nedenle Aristoteles, insan için en yüksek ve gerçek mutluluğun kuramsal bilim ve felsefede aklın hiçbir kayıt ve sınırlamaya tabi tutulmadan yaşama geçirilmesinde yattığı iddiasındadır (Büyükdüvenci, 1993, s. 43).

Görüldüğü üzere ölçülü bir şekilde çalışmaya izin veren Aristoteles, para kazanmanın dışında başka aktiviteler olduğunun farkındadır. O, insani faaliyetleri ekonomik etkinliklere indirgemez. Ona göre iyi yaşam, aktif bir yaşamdır, faaliyetlerle dolu bir yaşamdır. İyi yaşam, ayrıca kendi uğruna sevilen bir etkinlik olarak teoria etkinliğini de içerir. Ancak Aristoteles'e göre felsefi etkinliğin gerçekleştirildiği teorik yaşamı sürecek insan sayısı son derece azdır. $\mathrm{O}$, haz yaşamı, siyaset yaşamı ve teoria yaşamı olmak üzere belli başlı üç yaşam biçimi olduğunu ileri sürer. Aristoteles'e göre bu yaşam biçimleri arasındaki tercihlerinden ötürü "Çoğunluk, evcil hayvanların yaşamın seçmekle büsbütün köle gibi görünürler." (Aristoteles, 2009, s. 12) Buna karşın teoria yaşamını tercih eden ussal bakımdan seçkin bir azınlığın yaşamı "en iyi yaşam" olarak düşünülmekte ve bunların yaşamı en fazla mutluluk veren yaşam sayılmaktadır (Kanat, 2013, s. 213). Bunun anlamı, bir toplumda aslında çok az insanın mutlu bir yaşam sürebileceğidir.

SEFAD, 2021; (45): 337-354 
Günümüzde bir faaliyet olarak düşünülmeyen derin düşünme, Aristoteles için en insani ve en önemli faaliyettir ve ayrıca bu yön, insandaki tanrısal niteliktir. Ancak Aristoteles'e göre insan, bir tanrı olmayıp tanrı ile hayvan arasında ara bir konumdadır. $\mathrm{Bu}$ açıdan ahlaklılık da iki uç arasında denge kurmayı gerektirir. İnsan hayatının amacı, ne sadece hayvansal unsurun gelişmesinde ne de kendisi için imkânsız bir şey olan Tanrı haline gelmek olmayıp hayvani ve tanrısal özün tam ve ahenkli bir şekilde açılıp genişlemesidir. $\mathrm{Bu}$ çerçevede insan için en iyi şey de zihinle hayvani unsur arasındaki dengeden doğan mutluluktur (Weber, 1998, s. 86). İnsan, doğasını tam olarak gerçekleştirebilmek için hayvani doğasını yok saymak ya da reddetmek yerine, onu akıl yoluyla kontrol etmeli, rasyonel olmayan arzu, itki ve eğilimlerini bastırmadan eğitip düzene sokmalıdır. Şayet kişi bunları düzene sokamazsa bunlar insana hâkim olur ve onun rasyonel fonksiyonlarını faaliyete geçirmesini engelleyerek onu insanlıktan uzaklaştırır. Kişi, hayvani doğasını bastırıp yok saydığında da rasyonel ve sorumlu bir varlık olarak kendini gerçekleştirme imkânından mahrum kalır (Cevizci, 2018, s. 176).

Aristoteles, iyi yaşamı mutluluk olarak adlandırırken, iyi yaşamın erdemlere uygun yaşam olduğunu söyler. Ona göre bu durumda mutluluk, erdemlere uygun olan etkinliktir. İnsan erdemlere uygun olarak yaşayabilir ve en iyiye sahip olabilir (Aristoteles, 2016, s. 4143). İyi bir yaşamın ancak erdemlerle mümkün olduğunu ileri süren Aristoteles, erdemleri düşünce erdemleri ve karakter erdemleri olarak ikiye ayırır. Düşünce erdemleri eğitim sayesinde gelişirken, karakter erdemleri alışkanlıkla elde edilirler (Aristoteles, 2017, s. 41). Aristoteles, düşünce erdemleri olarak aklı başındalığı, kıvrak zekâyı, bilgeliği, öğrenmeye açıklı̆̆ ve hafızayı zikreder. Karakter erdemleri olarak da öncelikle ölçülülük, adalet ve yiğitlikten bahseder (Aristoteles, 2016, s. 47). Ancak karakter erdemleri bunlardan ibaret değildir. Aristoteles, Eudemos'a Etik'te sakinlik, utanmayı bilme, adalet, cömertlik, ciddiyet, dostluk, samimiyet gibi başka karakter erdemlerini de sıralar (Aristoteles, 1999, s. 57). Bütün bu karakter erdemleri orta yol olma durumlarıdır. Karakter erdemlerinde birer kötü durum olan eksiklik ve fazlalığın ortası bulunmaya çalışılır (Aristoteles, 2017, s. 53). Yiyecek ve içecekler çok ya da az tüketildikleri takdirde sağlığı bozdukları için bunların dengeli alınmaları gerekir. Erdemlerde de durum buna benzemektedir (Aristoteles, 2016, s. 47-49). Aristoteles, orta olanı uygun zamanda, uygun oranda, uygun insanlara karşı hareket etmek olarak tanımlar. Ancak tüm eylem ve etkilenimlerin ortasının iyi olduğu şeklinde bir kural olmadığını da belirtir. Hırsızlık ve cinayet gibi bazı eylemlerin bizzat kendileri kötüdür (Aristoteles, 2017, s. 49).

Aristoteles, karakter kelimesinin alışkanlık sözcüğünden geldiğini, ona alışkanlık kazanarak sahip olduğumuz için karakter dendiğini söyler; bundan ruhun akıl bulunmayan yanına ait erdemlerin hiçbirinin doğal olarak ortaya çıkmadığı sonucuna varır. Erdemler alışkanlığın eseridirler ve alışkanlıkları oluşturan da eylemlerdir. Eylemlerin ilkeleri ise tercih, istek ve akla karşıllk gelen şeylerdir. Bu nedenle insan eylemlerini değiştirme imkânına sahiptir. Kişi eylemlerini değiştirerek alışkanlıklarını, alışkanlıklarını değiştirerek de karakterini değiştirebilir. Bu yüzden Aristoteles, iyi ya da kötü biri olmanın bize bağlı olduğunu ileri sürer (Aristoteles, 2016, s. 61).

Karakteri değiştirmek mümkün olsa da bir orta yol olma durumu olan erdemi kazanmak kolay değildir. Karakter erdemi uzun tecrübeler sonunda insanda yerleşen erdemli olma halidir. Erdemler açısından çocukluk dönemi oldukça önemlidir. Eğer kişi, henüz çocukken ölçüsüz olma alışkanlığı kazanırsa ölçüsüzlük onun için doğal yolla 
kazandığı bir alışkanlık olacaktır. Bu nedenle Aristoteles, iyi alışkanlığın çocuklukta yerleştiğini düşünür. Örneğin çocuğa büyükleri tarafından yalan söylememesi tembih edilir. Çocuk doğruyu söylemenin taşıdığı iyiliği anlamaksızın tembihe uyar ve doğruyu söyleme davranışı aşamalı olarak alışkanlık haline gelir. Eğitim süreci ilerledikçe de doğru sözlü olmanın kendinde doğru olduğunu anlamaya ve onu yapılacak doğru şey olarak görüp doğru sözlü olmayı seçmeye başlar (Copleston, 2013, s. 74-75). Tekrarlayan eylemler alışkanlık haline dönüşürler. Benzer eylemler huyları doğururlar. Farklı eylemler de farklı huylar oluştururlar. Bu nedenle insanın gençliğinden itibaren erdemlere alışması ile alışmaması arasında çok büyük fark olmaktadır (Aristoteles, 2009, s. 31).

Aristoteles'e göre karakter erdemlerini tecrübe yoluyla kazanırız. Erdemler diğer sanatlar gibi etkinlikte bulunularak elde edilirler. Nasıl ki ev yapa yapa mimar, gitar çala çala gitarcı olunur; adil şeyler yapa yapa adil insan, ölçülü davrana davrana ölçülü, yiğitçe davrana davrana yiğit insan olunur (Aristoteles, 2009, s. 30). Karakter erdemleri alışkanlık neticesinde failden neredeyse akan bir şey haline gelir. Kişi erdemlere öyle alışır ki artık erdemli davranışta bulunmak için eylem öncesinde düşünerek zaman kaybetmez. Cesur insan kendiliğinden cesur davranır. Cömert insan, birisinin bir ihtiyacı söz konusu olduğunda kendiliğinden bir şeyler verir. Bir kimsenin durup eylemleri üzerinde düşünmesi, kendisine cesur veya cömert olup olmaması gerektiğini söylemesi onun bu erdemleri taşımadığını gösterir. Ayrıca erdemli insan erdemli olmaktan haz duyar. Yapması gereken şeyle yapmak istediği şey arasında bir çatışma olmadığ i için erdem ile bireysel çıkar arasında da bir gerginlik olmaz (Cevizci, 2018, s. 177-180). Aristoteles ahlakında insani arzu ve tutkular ahlaksallığa a priori karşıt gibi görülmemektedirler (Kanat, 2013, s. 197). Bu nedenle erdemli insanın içsel bütünlüğe sahip olduğu söylenebilir. Böyle bir insan için erdemli davranış, akıl ile arzular arasında yaşanan çatışmanın aklın zaferiyle sonuçlanması değildir. Arzular, duygular ve akıl arasındaki uyumun sonucudur.

Erdemlerin akışkanlıklar yoluyla elde edildiği düşüncesi, onun doğaya aykırı olduğu anlamına gelmemektedir. Aristoteles'e göre insanda bulunan erdemler ne doğadan gelirler ne de doğaya karşıt olarak oluşurlar. İnsanların doğal yapısı bunları edinmeye uygundur ve insanlar alışkanlık yolu ile onları tam olarak geliştirebilme imkânına sahiptir (Aristoteles, 2009, s. 30). Bu nedenle çocukluktan başlayacak bir eğitimle insanlar, tekrar tekrar erdemli davranışlar sergileyerek oluşacak alışkanlık neticesinde erdemli olabilecektir.

\section{DEVLETINN NE TÜR BİR EĞİTIMM VERECEĞİ MESELESİ}

Aristoteles, devleti siyasal bir topluluk olarak tanımlar (Aristoteles, 2013, s. 23). Ona göre bir topluluk olarak devletin ereği, insanın en yüksek iyisi, onun ahlaksal ve düşünsel yaşamıdır (Copleston, 2013, s. 90). Devlet düzleminde iyinin gerçekleşmesi, devlet yönetimi altındaki insanların her birinin kendi potansiyellerini edimselleştirmelerinin koşullarının yaratılmasıyla sağlanır (Yılmaz, 2010, s. 34). Bu nedenle yasa koyucunun özellikle gençlerle ilgilenmesine hiç kimse karşı çıkmayacaktır. Bütün kentin tek bir amacı olduğu için herkes için tek ve aynı eğitimin olması gerekir; bunun yönetimi de özel değil, kamusal olmalıdır (Barnes, 2002, s. 121).

Aristoteles'e göre yasa yapıcının ilk görevi gençlerin eğitimi ile ilgilenmektir. Çünkü bu yapılmadığı takdirde anayasa zarar görecektir. Anayasada eğitim konusuna mutlaka yer verilmelidir ve bu iş anayasaya göre yapılmalıdır (Aristoteles, 2013, s. 255). Yasa koyucunun amacı, yurttaşlarda iyi alışkanlıklar oluşturarak onları iyi hale getirmektir. Bunu iyi

SEFAD, 2021; (45): 337-354 
yapmayanlar amaçlarına ulaşamazlar. İyi yönetim tarzı ile kötüsü arasındaki farkı da bunu iyi yapıp yapamamak belirler (Burnet, 2008, s. 69).

Aristoteles, eğitimin, taşıdığı önem nedeniyle bireylerin kişisel tercihlerine bırakılmaması, devlet sorumluluğu altında yürütülmesi gerektiğini söyler. Eğitim, devletin sorumluluğu altında olmalıdır ve eğitimle ilgili her türlü düzenlemede insanın biyolojik ve psikolojik gelişimi göz önüne alınmalıdır. Bu açıdan eğitim kamusal olduğu kadar bireysel bir konudur. Bir yandan devlet meselesi olan eğitim, bir yandan da bireyin gelişimini amaçladığı için bireysel bir meseledir. Gerçek anlamda eğitim, yedi yaşında başlamalı ve yirmi bir yaşına kadar devam etmelidir. Eğitimin içeriği okuma-yazma, jimnastik, müzik ve resimden oluşmalı ve eğitim özel bir amacın gerçekleştirilmesine yönelik olmamalıdır. Eğitimde yalnızca özgürce düşünme, duyma ve yaratma amaçlanmalıdır. Diğer bir deyişle, gerçek bir eğitim, çocuğun yaşama ilişkin duygusal ve düşünsel bakımdan doğru şekilde gelişmesini amaçlamalıdır. Çünkü duygusal ve düşünsel bakımdan doğru şekilde yetiştirilmeyen çocuklar, yetişkinliğe eriştiklerinde yaşamın ereğini bulmakta ve oluşturmakta güçlük çekerler (Erkızan \& Çüçen, 2013, s. 156).

Aristoteles'in resim ve müzik gibi sanatlara eğitim müfredatında yer vermiş olması dikkate değerdir. Çünkü sanatlar insanların duygusal ve zihinsel gelişimleri açısından gerekli oldukları kadar yaratıcılıkları üzerinde de etkilidirler. Sanatların insanlar üzerindeki etkisi konusunda İnci San şu tespitlerde bulunur: Resim yapma, müzik besteleme, şiir yazma gibi yeteneğe bağlı, öğrenilebilen ve alıştırma yaparak geliştirilebilen etkinlikler yaratıcı faaliyetlerdir. Yaratıcılık insanlara özgü bir yetenektir ve her insanda az ya da çok bulunmaktadır. Sanat eğitiminin amaçlarından biri de görmeyi, işitmeyi, dokunmayı ve tatmayı öğretmektir ki böyle bir eğitim kişinin çevresini hakkıyla algılayıp onu biçimlendirmeye yönelmesi açısından gereklidir (San, 2019, s. 15-25).

Eğitim vermeyi devletin en önemli görevlerinden biri sayan Aristoteles, eğitimin ne şekilde verilmesi gerektiğini ayrıntılı bir şekilde ele alır. Ona göre eğitim meselesi, çocuk yedi yaşına basmadan, henüz okul çağına girmeden çok daha önce başlar. Çocuk doğmadan önce, hamilelik öncesi anne-baba adayının beden yapısının belli ölçülerde olması gerekir. Atletik bir bedene sahip olmak çocuk sahibi olmak için en uygun durumda olmak anlamına gelmediği gibi hastalıklı veya çalışamayacak durumda olmak da ebeveynlik için istenilir haller değildir. Bu açıdan orta durumda olmak, çok çalışmaktan ziyade iyi çalışmaya alışık olmak demektir. Bu hem kadınlar hem de erkekler için böyledir. Ancak kadınların ayrıca hamilelikleri sırasında da bedenlerine dikkat etmeleri beklenir. Hem iyi beslenmelidirler hem de egzersiz yapmalıdırlar. Bu nedenle yasa yapıcının, kadınların tapınağa gitmelerini zorunlu tutarak onları yürüyüş yapmaya zorlaması yerinde bir uygulamadır. Bitkilerin topraktan güç aldığını söyleyen Aristoteles, anneyi toprağa benzeterek doğmamış bebeklerin de iyiliklerini annelerinden aldıklarını iddia eder (Aristoteles, 2013, s. 251). Aristoteles'in anne adayının sağlığını koruması ile ilgili önerileri ile onun toprak ve bitki ile anne ve bebek arasında yaptığı analoji göz önünde bulundurulduğunda burada kastedilen iyiliğin bebeğin bedensel sağllğı olduğu sonucuna varılabilir. Aristoteles iyileri diş iyiler, ruhla ilgili iyiler ve bedenle ilgili iyiler olarak üçe ayırmıştır (Aristoteles, 2009, s. 19). Ona göre bu iyilerden ruhsal iyiler sınıfına dahil olan akli yetkinlik kadınlarda bulunmaz. Bu nedenle anne adayı, hamilelik süreci içinde sağlığına dikkat ederek doğacak bebeğin bedensel iyiliğine katkıda bulunacaktır. 
Aristoteles, çocuğun doğum sonrası bakımı ile ilgili de birtakım tespit ve tavsiyelerde bulunur. Ona göre doğduktan sonra bebeğe gerekli besinin verilmesi onun gelişimi açısından çok önemlidir. Bu dönemde bol miktarda süt içirilmesi gereken çocukların yapabilecekleri kadar bedensel hareket yapmaları da gerekir. Diğer yandan çocukların erken yaşlardan itibaren yavaş yavaş soğuğa alıştırılmaları, hem sağlıklı olmalarını hem de savaş̧̧ılık özelliği kazanmalarını sağlayacaktır. Bebeklik dönemi için bunları söyleyen Aristoteles, çocukların beş yaşına kadarki süreçleri konusunda bu dönemde onlara bir şeyler öğretmenin ya da onların gelişimini engelleyecek şeyler yapmanın doğru olmadığı uyarısında bulunur. Bu dönemde çocuklar hareketsiz bırakılmamalıdırlar ve çok yorucu olmayan, bir mantığı olan oyunlar oynamalıdırlar (Aristoteles, 2013, s. 252-253).

Okul öncesi çocukların eğitimlerinin ne şekilde olması gerektiğini açıklayan Aristoteles konuya ilişkin ayrıca şunları söyler: Dadılar bu çocuklara ne tür masallar anlatacaklarını önceden belirlemelidirler. Çünkü bu dönemde dinledikleri şeyler onlar için okul dönemine hazırlık niteliğindedir. Bu yüzden oynadıkları oyunlar da onları daha sonraki dönemlerde yapacakları şeylere hazırlamak amacını taşımalı ve onları heveslendirecek türden olmalıdır. Çocukların ağlamalarının ve ciğerlerinin genişletilmesinin engellenmesini yanlış bulan Aristoteles, ağlamayı bedenin gelişmesi açısından önemli bir hareket olarak kabul eder. Aristoteles'e göre insanlar, küçük yaştaki çocukların eğitiminde oyun, hareket ve dinlenmenin yanı sıra çocukların, kölelerin yanında fazla kalmaması konusunda da dikkatli olmalıdır. Çünkü yedi yaşına kadar olan çocuklar mecburen evde kalırlar ve bu nedenle kölelerden asil olmayan şeyler öğrenmeleri kuvvetle muhtemeldir. Ayrıca çocuklar patavatsızlık olarak kabul edilen şeylerden uzak tutulmalı, bunları görmeleri ve duymaları engellenmelidir (Aristoteles, 2013, s. 254).

Aristoteles, çocukların kötü etkilerden korunması konusunda son derece hassastır. Onun bu endişesi, müzik eğitiminde kullanılacak müzik aletleri konusundaki tercihini de etkiler. Ona göre aşırı derecede heyecan uyandıran flüt iyi bir müzik aleti değildir. Bu nedenle flüt, eğitimden ziyade duyguların arındırılması amacıyla kullanılmalıdır (Burnet, 2008 , s. 167). Aristoteles, aynı kaygıyla eğitimde her melodi ve usule yer verilmemesi gerektiğini de söyler. Ona göre eğitimle ilgili amaçlar bakımından ahlaki melodiler ve usuller kullanılmalıdır (Burnet, 2008, s. 173). Öğrencinin köleler, çocuklar ve çeşitli hayvanların hoşuna giden müzikten ziyade güzel melodi ve ritimleri tercih edebileceği bir noktaya kadar eğitilmesi gerektiğini söyleyen Aristoteles'e göre üflemeli çalgıların, kithara ya da benzer müzik aletlerinin eğitimde yeri yoktur. Bu tür müzik aletleri, insanların duygularını harekete geçirmek, onları canlandırmak içindir. İnsan aklına olumlu etkisi olmayan bu müzik aletleri ahlaki değildirler (Aristoteles, 2013, s. 265-266). Çocukların ve gençlerin çevrelerindeki uyaranlardan kolayca etkilenebileceğini, onların kendilerini bu etkilerden koruyacak seviyede olmadığını düşünen Aristoteles, eğitimde müzik dersinin ne şekilde verileceği konusunu da bu düşünceye göre belirler. Bu çerçevede aşırı heyecan uyandıran müzik aletlerinin eğitimde kullanılmasını doğru bulmayan Aristoteles, melodi ve usullerin de ahlaki nitelikte olması gerektiğini belirtir.

Aristoteles, beş yaşından sonra çocukların gözlem yoluyla öğrenmeye başladıklarını ileri sürer ve sonrasında verilen eğitimi iki döneme ayırır. İlki, yedi yaş ile ergenlik arasındaki, ikincisi ise ergenlik ile yirmi bir yaş arasındaki dönemi kapsar. Aristoteles, kendi döneminde çocuklara verilen eğitimin hangi konuları içerdiğine ilişkin gözlemlerini aktarır.

SEFAD, 2021; (45): 337-354 
Onun döneminde Atina'da çocuklara öğretilen şeyler temelde şunlardır: Okuma-yazma, beden eğitimi, müzik ve kısmen resim (Aristoteles, 2013, s. 254-257).

Aristoteles, okuma-yazma, beden eğitimi, müzik ve resim becerilerinin kazandırılmasının uygunluğunu değerlendirir. Okuma-yazma ve resim becerilerinin günlük hayatta büyük fayda sağladığından kuşkusu olmayan Aristoteles, beden eğitiminin de cesaret esinlediğini ve bu nedenle eğitim müfredatında yer alması gerektiğini düşünür. Fakat müziğin durumu biraz şüphelidir. Çoğu insan müziğin amacının zevk olduğunu düşünerek onunla ilgilenir. Oysaki eskiler, sadece doğru şekilde meşgul olmayı değil, aynı zamanda serbest zamanı doğru kullanmayı da amaçladıkları için müziğe yer vermekteydiler (Burnet, 2008, s. 152). Okuma yazma öğrenmek bir iş yapmaya, resim bilgisine sahip olmak sanat eserlerini doğru değerlendirmeye, beden eğitimi daha sağlıklı ve zinde bir beden elde etmeye yarar. Bunların hiçbirini sağlamayan müzikle tek bir şey amaçlanır: Boş zamanların doğru şekilde değerlendirilmesi (Aristoteles, 2013, s. 257-258).

Eğitim müfredatında müziğe yer verilmesi gerektiğini söyleyen Aristoteles, bu eğitimin eğlence amaçlı olmadığı konusunda uyarıda bulunur (Aristoteles, 2013, s. 260). Ayrıca müzik öğretimi, çocukların daha sonraki etkinliklerini engelleyecek veya bedenlerini mekanikleştirip onları askerlik ve yurttaşlık faaliyetleri bakımından elverişsiz hale getirecek türde olmamalıdır. Öğretimde amaç, ne sadece mesleki gösteriler için gerekli olan şeyleri ne de göz boyayıcı icra harikalarını kazandırmaktır (Burnet, 2008, s. 166-167). Müzik ve beden eğitiminin eğitim müfredatında yer alması taraftarı olan Aristoteles, bu eğitimin ne şekilde verilmesi gerektiği sorusuna etik anlayışını andıran bir yaklaşımla yanıt verir. Müziğin ve beden eğitiminin kuşkusuz eğitim hayatında bir yeri olacaktır ancak bu derslere 1 lımlı bir şekilde yer verilmelidir. Her müzik aleti ve her melodi eğitimde kullanılmayacağı gibi çocuklar spor için de çok fazla zaman harcamayacaklardır.

Eğitim ile erdemi amaçlayan Aristoteles, Platon'un çocukluktan itibaren güzel şeylerden haz almayı ve kötü şeylerden acı çekmeyi öğretecek bir eğitim öngördüğünü belirterek bu konuda Platon'u onaylar (Aristoteles, 2017, s. 44). Erdeme öncelik taniyan Aristoteles'e göre ruhun akıllı bölümü, akıllı olmayan bölümünden, akıllı bölümüne ilişkin erdemler de diğer bölümüne ilişkin erdemlerden daha üstün olduğu için eğitimde en çok önem verilmesi gereken şey, teorik erdemleri geliştirmektir. Ancak bundan sonra sırasıyla karakter erdemlerinin ve bedensel iyilerin gelişimi göz önüne alınmalıdır. Öncelik bakımından böyle bir sıralama ortaya koyan Aristoteles, zamansal bakımdan tam tersi bir sıralama yapar. Bu ikinci sıralamaya göre bedenin eğitimi ruhun eğitiminden önce gelir ve ahlaki eğitim beden eğitimini takip eder. Aklın eğitimi olan teorik eğitim ise son sırada yer alır (Arslan, 2018, s. 321). Eğitimin beden ile başlamasının nedeni, beden ve itkilerin ruhtan ve ruhun yetilerinden daha erken gelişmesidir. Beden ve itkileri eğitilirken gözetilen amaç yine ruhun ve yetilerinin eğitilmesidir (Copleston, 2013, s. 96).

Aristoteles'e göre devletin amacı soylular sınıfı düşüncesini, öğrenme ve sanat sevgisiyle birleştiren kültürlü beyefendiler yetiştirmektir. Bu nedenle çocukların kendileri için yararlı olanı ve bozucu olmayanı öğrenmeleri gerekir. Aristoteles, öğrenciler için yararlı olmadığını veya bozucu olduğunu düşündüğü vücut şeklini bozan ya da onlara para kazanma yeteneği kazandıran bir ustalığın onlara öğretilmeyeceğini, onların profesyonel bir ustalığa varmayacak şekilde ılımlı olarak atletizmle uğraşacaklarını söyler (Russell, 2002, s. 335). Eğitimle, para kazanma becerilerini elde etmeyi ya da profesyonel düzeyde beden eğitimini amaçlamayan Aristoteles'e göre eğitimin amacı yurttaşların erdem kazanmasıdır, 
yurttaşın yurttaş olarak eğitimidir. Yurttaş sırayla ve zamanla yönetilen ve yöneten olacağ için onda hem yönetilme hem de yönetme ile ilgili erdemlerin geliştirilmesi gerekir. Yurttaş, hem yasalara karşı itaatkâr hem de yasa yapmaya, yürütme gücünü ifa etmeye yetenekli olacak şekilde yetiştirilmelidir (Arslan, 2018, s. 321).

Aristoteles çocuklara vazgeçilmez türden yararlı şeyleri öğretmek gerektiğinden kuşku duymaz. Ancak ona göre her türlü yararlı bilgi de eğitim için uygun değildir. $\mathrm{O}$, özgür bir kimseye yakışan ve yakışmayan konular arasında bir ayrım yapar ve ancak özgür kişilere yakışan, onları mekanik hale getirmeyecek türden bilginin, eğitimin bir parçası olacağını belirtir. Mekanik konular ile özgür kimselerin bedenini, ruhunu ve aklını erdemin icrası veya tatbiki açısından işe yaramaz hale getiren bütün sanatları ve çalışmaları kast eder, bedenin biçimini bozabilecek sanatlara ve para karşıllı̆̆ yapılan işlere mekanik der. Bunlar düşüncenin serbest kalmasını engelleyeceği, onu sürekli aşağı düzeye çekeceği için eğitim müfredatında yer almamalıdırlar. Bunların dışında belli bir noktaya kadar özgür kimselerin edinmesinin değersiz olduğu söylenemeyecek bazı sanatlar da vardır fakat bunlarda mükemmelliğe ulaşmak için çok fazla uğraşılacak olursa aynı kötü sonuçlar ortaya çıkacaktır (Burnet, 2008, s. 149-151).

Aristoteles, eğitim müfredatını belirlerken özgür kişilerin ve kölelerin yaptığı işlerin mahiyetini esas alır. Bu ölçüte göre özgür yurttaşlara verilecek eğitimin müfredatında kölelere yakışan, köleler tarafından icra edilen beceriler bulunmamalıdır. Bu tarz bedensel sanatlar yararlı olmakla beraber insanın zihinsel yetilerini zayıflatacağı ve insana özgü erdemlerin ortaya çıkmasını engelleyeceği için özgür yurttaşların çocuklarına öğretilmemeleri daha doğrudur.

Aristoteles'in eğitim anlayışını belirleyen en önemli unsurlardan biri köleler ile özgür yurttaşlar arasında kurduğu karşıtlıktır. Ona göre çoğunlukla bedensel işlerde çalıştırılan kölelerin yaşamı özgür erkeklerin yaşamından çok daha az değerlidir. Çünkü köle ona sahip olanın malıdır, değerini fiziki yeteneklerinden alır (Brun, 2008, s. 118). Bu düşüncenin anlaşılması için Aristoteles'in yaşadığı dönemde kölelerin insan olarak kabul edilmediği akılda tutulmalıdır (Pieper, 1999, s. 138). O dönemde köle doğası insansal olandan daha az değerli bir şey olarak görülmekteydi (Copleston, 2013, s. 92). Aristoteles için de bazı insanlar o derece bayağı ve hayvanidirler ki bunların bir efendinin iradesi altına girmeleri kendi başlarına bırakılmalarından daha iyidir (Kenny, 2011, s. 110). Kölelerin bedensel işlerde kullanımını onaylayan Aristoteles, bunlara aşçılık ve ev işleri gibi konularda eğitim verilebileceğini söyler (Aristoteles, 2013, s. 31-34). Okullarda verilen eğitimle bir ilgisi bulunmayan bu eğitimle kölelere birtakım beceriler kazandırmak amaçlanır ki Aristoteles bunu gerçek bir eğitim olarak görmez.

Aristoteles'in köleler ve özgür yurttaşlar için uygun gördügü bilgi ve beceriler büyük ölçüde farklıdır. $O$, kölelere basit gündelik işleri yapmak için gerekli becerilerin kazandırılmasını, özgür yurttaşlar için ise pratik ve teknik konuların ötesinde, özellikle aklı yetkinleştirecek bir eğitimi gerekli görür. Aristoteles'e göre bu farkın temel nedeni, kölelerin doğaca aklı kullanma bakımından yetersiz oluşlarıdır. Dolayısıyla Aristoteles için eğitimin içeriğini belirleyen asıl faktör, kişilerin statülerinden ziyade bu statülerin ortaya çıkmasına neden olan doğal farklılıklardır. Bu açıdan bakıldığında her türlü eğitimde eşitsizliğin mevcut olduğu görülmektedir. Durkheim'ın da belirttiği üzere eğitimde heterojenlik haksız eşitsizliklere dayanmadığı sürece bir eksiklik değildir. Tamamen homojen ve eşitlikçi bir eğitim, hiçbir farklılaşmanın olmadığı tarih öncesi dönemlerde görülmüştür ve bu tarz 
toplumlar insanlık tarihinde belirli bir evre dışında hiç görülmemiştir (Durkheim, 2016, s. 51). Aristoteles'in içinde yaşadığı dönemde de kölelik-efendilik ayrımına bağlı olarak ortaya çıkmış heterojen bir eğitim yapısı vardı. Aristoteles, kölelik ve efendiliği o insanların doğal yapılarına bağlayarak, bu ve diğer konulardaki eşitsizliği meşrulaştırmaya çalışmıştır. Burada eleştirilebilecek üç nokta vardır: İlki, onun bu sınıflar için yaptığ 1 ayrımın haklı çıkarılıp çıkarılamayacağı, yani kölelerin aklı kullanma yetilerinin Aristoteles'in söylediği gibi yetersiz olup olmadığıdır. İkincisi ise bazı insanların aklı kullanma yetilerinin yetersiz olmasının, onların birer araç olarak kullanılabileceği anlamına gelip gelemeyeceğidir. Üçüncüsü de kadınlar hakkında ileri sürdüğü olumsuz görüşlerdir.

\section{SONUÇ}

Aristoteles, eğitim ile erdemli yurttaşların yetiştirilmesini ve insani potansiyellerin dengeli bir şekilde açığa çıkarılmasını amaçlar. Eğitimin bu amaçları Aristoteles için oldukça önemlidir ve bu nedenle bir devletin en önemli görevlerinden biri, belki de en önemlisi, eğitimle ilgili düzenlemeler yapmaktır. İyi yurttaşların yetiştirilmesini hedefleyen hiçbir devlet, kamusal bir mesele olan eğitim konusuna kayıtsız kalamaz ya da eğitim işini kişilerin kendi tercihlerine bırakamaz. Eğitim hem yurttaşların iyi bir şekilde yetiştirilmesini hem de onların birtakım bilgi ve beceriler kazanmasını sağlayacaktır. Bu sayede devlet istikrar ve düzen kazanacağı gibi yurttaşlar da iyi yaşam imkânına kavuşacaktır. Eğitimin gerekliliği geçmişten çok daha fazla olmak üzere günümüz dünyasında geçerlidir. Ulaşım imkânlarının kısıtlı olduğu, insanların çok basit aletler kullanarak yaşadığı, hayatın her alanını kuşatan prosedürlerin olmadığı antik dönemde bile eğitim bir ihtiyaçken, her bakımdan ondan çok daha karmaşık olan bugünün dünyasında eğitim tüm toplumların en temel meselelerinden biridir. Şu farkla ki günümüzde eğitim, insan merkezli değil, ekonomi merkezli olarak yürütülmektedir. Günümüz dünyasında eğitime fazlasıyla kâr odaklı bir şekilde bakılmaktadır ve teknik konulardaki eğitim merkeze alınmaktadır. İnsanlara para kazanmayı sağlayacak beceriler kazandırmayı amaçlayan eğitim sistemleri, onların ahlaki ve zihinsel gelişimlerini dikkate almamaktadır. Oysa iyi bir yaşam kişinin ahlaki, bedensel, duygusal ve düşünsel açıdan bütünlüklü bir şekilde gelişmesi ile mümkündür. İnsanların mutluluğunu hedefleyen her türlü eğitim faaliyeti bu gerçek dikkate alınarak düzenlenmelidir. Yalnızca teknik konulara ve bedensel becerilere ağırlık veren bir eğitim sistemi öğrencilerin düşünsel, duygusal ve ahlaki yönlerden cılız kalmasına neden olacaktır.

Aristoteles, devletin eğitim hizmeti vermesi ve eğitimin içeriğini belirlemesi gerektiğini söylerken, adeta günümüz dünyasından bahsetmektedir. Bilindiği üzere modern dünyada eğitim kamusal bir mesele olarak görülmektedir. Modern devletlerin hepsi vatandaşlarına eğitim hizmeti sağlamaktadır. Ancak konu eğitimin kimlere verileceği sorusuna geldiğinde, Aristoteles'in meseleye bir Antik Yunan toplumu üyesi olarak yaklaştığı görülür. Onun bu konudaki görüşleri, hocası Platon'unkilerden oldukça farklıdır. Bilindiği üzere Platon, hem cinsiyete bakılmaksızın kız ve erkek tüm çocuklara eğitim verilmesi gerektiğini hem de asıl olanın soy sop olmayıp kişinin taşıdığı nitelikler olduğunu ve bu nedenle toplumun her kesimine eğitim fırsatı sunulması gerektiğini savunmuştu. Oysa Aristoteles, köle çocuklarını ve kız çocuklarını bir kenara bırakarak yalnızca özgür yurttaşların erkek çocuklarına eğitim verilmesi gerektiğini söyler. Bu açıdan Aristoteles'in içinde yaşadığı Antik Yunan toplumunun ön kabullerini aşamadığı ve Platon'un gerisinde kaldığı söylenebilir. Aristoteles, yalnızca özgür erkek çocuklarına eğitim verilmesi gerektiğini savunurken, kölelerin ve kadınların özgür erkeklere nazaran daha yetersiz bir 
akla sahip olduklarını iddia etmiş ancak bunun için geçerli bir kanıt göstermemiştir. Kanıtlanmamış bir iddia üzerinden insanları sınıflandırmanın haklı bir tarafı yoktur. Öte yandan bazı insanlar gerçekten de akıl bakımından diğer insanlara göre daha yetersiz olabilirler. Ancak bu durum onların köle olarak kullanılmaları için geçerli bir neden olamaz. Aslında insanların köle olarak kullanılmasını meşrulaştıracak hiçbir gerekçe yoktur. Tüm insanlar insan oldukları için çeşitli haklara ve insanca muamele görmeye layıktırlar. Bütün bunlara rağmen Aristoteles'in yaptığı bu ayrımcılık değerlendirilirken, toplumsal farklılaşmanın olduğu hiçbir toplumda homojen bir eğitimin yapılamayacağı gerçeği unutulmamalıdır. Bu nedenle Aristoteles'in, farklı eğitim biçimlerini savunması değil, toplumun farklı kesimleri için uygun gördüğü eğitim biçimlerinin haklı bir zemine mi dayandığı yoksa haksız bir eşitsizlikten mi kaynaklandığı tartışılmalıdır. Diğer yandan Aristoteles, devletin eğitim verirken amacının iyi insanlar yetiştirmek olduğunu, böylece yetişen insanların iyi bir yaşama ve mutluluğa kavuşacağını söylerken, modern devletlerin iyi insan ve iyi yaşam gibi kavramları gereği gibi önemsemedikleri görülmektedir. Modern devletler, yurttaşlarını teknik bilgilerle donatırken, ahlaki anlamda iyi insan olmayı ve mutluluğa ulaşmayı onların şahsi meselesi olarak kabul etmektedirler.

Genel olarak bakıldığında Aristoteles'in eğitime ilişkin çok önemli tespitlerde ve uyarılarda bulunduğu görülmektedir. İyi bir insanın veya yurttaşın yetiştirilmesi meselesini okul çağı ile sınırlandırmayarak, doğum öncesi, bebeklik ve ilk çocukluk dönemi ile beraber ele almış ve bütüncül bir yaklaşım sergilemiştir. Şu an pedagoji, psikoloji gibi bazı bilim dallarının ortaya koyduğu sonuçlar, bu konuda Aristoteles'i haklı çıkarmaktadır. Bu bilim dalları, bebeğin anne karnında geçirdiği sağlıklı sürecin onun ileriki yaşamında oynadığı rolü ortaya koymaktadırlar. Ayrıca yine günümüz bilimleri, çocuğun tehlikelerden korunması koşuluyla çok fazla engellenmeden serbestçe hareket etmesi gerektiğini söylerken Aristoteles'le hemfikirdirler. Diğer yandan günümüz bilimleri, Aristoteles'in çocuğun zarar görecek etkilerden uzak tutulması gerektiği uyarısını da onaylamaktadırlar. Kişinin eğitimi yalnızca bilinçli faaliyetlerden oluşmamaktadır, bilinçdışını etkileyen faktörler de eğitime sürekli etki etmektedir. Bilindiği üzere bazı uyarıcılar çocuklar üzerinde travmatik etkiler yaratarak onlarda kalıcı etkiler yaratabilmekte ve onun zihinsel, psikolojik ya da ahlaki gelişimini sekteye uğratabilmektedirler. Bu nedenle çocuğun eğitiminde bilinçli eğitim faaliyetleri kadar onun bilinçdışını etkileyen unsurlar da dikkate alınmalıdır.

Aristoteles'in eğitime dair öne sürdügü görüşlerden dikkat çekici olan diğer bazı düşünceler eğitim müfredatına ilişkin olanlardır. Bu düşünceler, hem eğitim müfredatını neyin oluşturacağı hem de bu müfredatın nasıl bir sıralama ile sunulacağı ile ilgilidirler. Okuma-yazma, resim, müzik ve beden eğitiminin müfredatta olması gerektiğini söyleyen Aristoteles, eğitim müfredatının yalnızca faydalı becerilerden oluşmayacağını, sadece para kazandıracak becerilere odaklanılmayacağını söyler ve sadece bunlara ağırlık verildiği takdirde mekanik insanların yetişeceği uyarısında bulunur. Eğitim, belli ölçülerde bedensel beceriler kazandıracak olsa bile ahlaki ve akli yetileri geliştirmek her zaman için daha öncelikli olmalıdır. Ahlaki kaygılar ve iyi insan olma düşüncesi Aristoteles'in eğitim anlayışının merkezinde bulunur ve diğer konular bunlar ekseninde ele alınır. Onun ahlaka ve erdeme ilişkin görüşleri, eğitim anlayışını da şekillendirir. Bu nedenle erdemi sağlayan şeyin orta yol olduğu şeklindeki etik öğretisinin izleri eğitim anlayışına da yansır. Orta yolun erdem olduğunu söyleyen Aristoteles, eğitimde de aşırılıklara karşıdır. Eğitim yalnızca akla yönelik olamayacağ gibi sadece bedensel becerilere yönelik de olamaz. Onun eğitim anlayışına göre beden, ahlak ve akıl herhangi biri ihmal edilmeden dengeli ve 
bütünlüklü bir şekilde eğitilecek ve bunun sonucunda iyi alışkanlıklara sahip erdemli yurttaş ortaya çıkacaktır. Onun eğitimde resim, müzik gibi sanatlara yer vermesi de oldukça mühimdir. Bu tür sanatlar, kişinin dünyayı ve kendisini daha farklı bir şekilde algılamasını sağlayabileceği gibi yaşamını da zenginleştirecektir. Güzel sanatlar, özellikle müzik, serbest zamanın değerlendirilmesi bakımından oldukça önemlidir.

Eğitim meselesini geniş bir perspektif içinde ele alan Aristoteles, belli bir insan anlayışından hareket etmiştir. Bu insan, doğası gereği bilmek isteyen, aklını kullanma yeteneğine sahip olan insandır ki Aristoteles için bu insan, Atina Devleti'nin özgür yurttaşında somutluk kazanmıştır. İçinde yaşadığı toplumun kabullerinden yola çıkan Aristoteles'in köleler ve kadınların eğitimine ilişkin söylediği şeyler bir kenara bırakılacak olursa, onun eğitimle ilgili söylediği şeylerin göz ardı edilemeyecek kadar önemli olduğu görülecektir. İnsana ve onun potansiyellerine bakarak bu potansiyellerin nasıl açığa çıkarılacağı sorusundan hareketle eğitim anlayışını oluşturan Aristoteles, eğitim yoluyla insanlaşmanın nasıl gerçekleşeceğine ilişkin bütüncül ve kapsamlı bir kuram oluşturmuştur.

\section{SUMMARY}

Aristotle dealt with the subject of education in the context of a well-raised person and put forth his basic principles regarding education in his work titled Politics. Aristotle claims that a person cannot be a good person alone, but that this is possible only in a good state. He believes that if nature, habits and mind are in harmony in a human being, s/he will be good and virtuous and attain a good life, and this will be achieved through education. Providing this education is one of the basic duties of the state. For Aristotle, the good life is only possible through virtues, and without the good life one cannot achieve happiness. Of course, happiness is not possible without some external conditions, but internal conditions are at least as necessary for happiness as external conditions. The inner good referred to as inner conditions are virtues, which Aristotle divides into virtues of thought and virtues of character. According to Aristotle, the human being resembles gods with his theoretical activity and this activity provides him/her with full and true happiness. In order for a person to have a good life, s/he must have the virtues of character as well as the virtues of thought. The essence of these virtues is that they are based on the doctrine of mean. Character virtues lie in the midst of lack and excess, so they are neither incomplete nor too many.

Aristotle considers a good life is same as happiness, and for a good life, the virtues of thought and character are required. However, according to him, not everyone will be able to acquire these virtues; therefore, they will not be able to attain good life and happiness. One of the main reasons for this is that not everyone's nature is suitable for these virtues. Aristotle makes a distinction between free men, women, and slaves, and argues that segments other than free men do not have a competent mind because of their nature. Therefore, women and slaves cannot have the same rights and responsibilities as free men. This also applies to education. For this reason, Aristotle excludes women and slaves from education.

According to Aristotle, the education that free citizens will receive should be a type of education that befits free people. For this reason, mechanical subjects should not be included in education. Aristotle, who refers to the works that render the body, spirit and mind useless in terms of performing their virtues as a result of mechanical skills, does not see the acquisition of such skills as education and strongly opposes to including them in education. 
To him, since they will contribute to the physical and mental development of the person, the education curriculum should include literacy, painting, music and physical education lessons.

Aristotle discusses the issue of education in a comprehensive way by emphasizing the concern for good life, starting from the period before the birth of the child, with questions such as who will receive education, how the education will be given, and what kind of education should be given at what times. In this study, in which descriptions and analysis methods were used predominantly, it was aimed to evaluate Aristotle's views on education from the perspectives of the state and the individual. While doing this, the importance of education was pointed out, and the purpose of education for Aristotle and the relationship of education with good life, happiness and virtue were attempted to be revealed. Subsequently, the type of the education curriculum Aristotle suggested was explained with its justifications.

Makale Bilgileri

Etik Kurul Karart:

Katılımcı Rızası:

Mali Destek:

Çıkar Çatışması:

Telif Haklart:
Etik Kurul Kararından muaftır.

Katılımcı Yok

Çalışma için herhangi bir kurum ve projeden mali destek alınmamıştır.

Çalışmada kişiler ve kurumlar arası çıkar çatışması bulunmamaktadır.

Telif hakkına sebep olacak bir materyal

kullanılmamıştır.

Article Information

Ethics Committee Approval:

Informed Consent:

Financial Support:

Conflict of Interest:

Copyrights:
Exempt from the Ethics Committee Decision.

No participant

No financial support from any institution or project.

No conflict of interest.

No material subject to copyright is included. 


\section{KAYNAKÇA}

Akdemir, E. (2010). İnsan felsefesi: Epiktetos ve Marcus Aurelius örneği. İstanbul: Birey Yayıncilik.

Aristoteles, (1999). Eudemos'a etik. (S. Babür, çev.). Ankara: Dost Kitabevi Yayınları.

Aristoteles, (2009). Nikomakhos'a etik. (S. Babür, çev.). Ankara: BilgeSu Yayıncılık.

Aristoteles, (2013). Politika. (F. Akderin, çev.). İstanbul: Say Yayınları.

Aristoteles, (2016). Magna moralia, (Y. Gurur, çev.). İstanbul: Pinhan Yayıncılık.

Aristoteles, (2017). Nikomakhos'a etik. (F. Akderin, çev.). İstanbul: Say Yayınları.

Arslan, A. (2018). İlkçağ felsefe tarihi 3. İstanbul: İstanbul Bilgi Üniversitesi Yayınları.

Barnes, J. (2002). Aristoteles. (B. Ö. Düzgören, çev.). İstanbul: Altın Kitaplar Yayınevi.

Brun, J. (2008). Aristoteles ve lise. (İ. Yerguz, çev.). İstanbul: Dost Kitabevi.

Burnet, J. (2008). Aristoteles eğitim üzerine. (A. Aydoğan, çev.). İstanbul: Say Yayınları.

Büyükdüvenci, S. (1993). Aristoteles'te Mutluluk Kavramı, Felsefe dünyası 9, 41-45.

Cevizci, A. (2018). Etik/ahlak felsefesi. İstanbul: Say Yayınları.

Copleston, F. (2013). Aristoteles. (A. Yardımlı. çev.). İstanbul: İdea Yayınevi.

Durkheim, E. (2016). Eğitim ve sosyoloji. (P. Ergenokon. çev.). İstanbul: Pinhan Yayıncllık.

Erkızan, H. N. B. (2013). Aristoteles yazıları/varlık, bilgi ve yaşam üzerine. Ankara: Sentez Yayıncilik.

Erkızan, H. N. \& Çüçen K. (2013). Antik çă̆ ve orta çă̆ felsefesi tarihi. Ankara: Sentez Yayıncilik.

Erkızan, H. N. (2016). Aristoteles: Yaşamı, Yapıtları ve Felsefesi. Özne Aristoteles özel sayısı, 752.

Erkızan, H. N. B. (2012a). Aristoteles yazılarl/etik ve politika üzerine. İstanbul: Sentez Yayıncılık.

Erkızan, H. N. B. (2012b). Aristoteles'ten Nussbaum'a insan. İstanbul: Sentez Yayıncılık.

Jung, C. G. (2019). Kişiliğ̈in gelişimi. (D. Olgaç, çev.). İstanbul: Pinhan Yayıncılık.

Kanat, C. A. (2013). Platon ve Aristoteles'te devlet ve toplum felsefesi. İstanbul: Doruk Yayımcilık.

Kenny, A. (2011). Batı felsefesinin yeni tarihi 1. cilt antik felsefe. (S. Uslu, çev.). İstanbul: Küre Yayınları.

Küçükalp, D. (2019). Siyaset Etiği. Etik ve etik sorunlar. (C. Türer, ed.). Ankara: Nobel Akademik Yayıncilık.

Laski, H. J. (2019). Politikaya giriş. (M. Koçakgöl, çev.). Ankara: Fol Kitap.

Nussbaum, M. C. (2018). Yapabilirlikler yaratmak: insani gelişmişlik yaklaşımı. (S. Somuncuoğlu, çev.). İstanbul: İletişim Yayıncılık.

Pieper, A. (1999). Etiğe giriş. (V. Atayman \& G. Sezer, çev.). İstanbul: Ayrıntı Yayınları.

Rescher, N. (2019). 101 Anekdotta felsefe tarihinde yolculuk. (A. Yılmaz, çev.). İstanbul: Vakıfbank Kültür Yayınları.

Ross, D. (2011). Aristoteles. (A. Arslan, çev.). İstanbul: Kabalcı Yayıncılık.

Russell, B. (2002). Batı felsefesi tarihi 1. (M. Sencer, çev.). İstanbul: Say Yayınları.

San, İ. (2019). Sanat ve eğitim. Ankara: Ütopya Yayınevi.

Weber, A. (1998). Felsefe tarihi. (H. V. Eralp, çev.). İstanbul: Sosyal Yayınlar.

Yılmaz, M. (2010). Aristoteles'te Eğitim Kavramının Politik İşlevi. Kayğ 15, 29-40. 